\title{
Characterization of strains related to brown ring disease outbreaks in southwestern Spain
}

\author{
D. Castro ${ }^{1}$, E. Martinez-Manzanares ${ }^{1}$, A. Luque ${ }^{1}$, B. Fouz ${ }^{2}$, M. A. Moriñigo ${ }^{1}$, \\ J. J. Borrego ${ }^{1}$, A. E. Toranzo ${ }^{2}$ \\ ${ }^{1}$ Departamento de Microbiología, Facultad de Ciencias, Universidad de Malaga, E-29071 Malaga, Spain \\ 2 Departamento de Microbiología y Parasitología, Facultad de Biología, Universidad de Santiago de Compostela, E-15706, \\ Spain
}

\begin{abstract}
Several characteristics, including biochemical, serological, drug resistance and plasmid profiles, of strains isolated from clams in southwestern Spain affected with brown ring disease have been comparatively studied. On the basis of 36 standard physiological and biochemical tests, all strains isolated were included in the genus Vibrio and further divided into 6 groups. The groups were differentiated on the basis of only 8 phenotypic traits: growth at $35^{\circ} \mathrm{C}$, arginine dihydrolase, gelatinase production, Voges-Proskauer and ONPG tests, and acid production from sucrose, amygdalin and mannitol. Applying these characteristics, the strains resembled Vibrio pelagius and $V$. splendidus species. However, the isolates of each group showed no cross-reactions with the antisera raised against several reference strains of different species of Vibrio, including $V$. anguillarum, $V$. tubiashii, $V$. damsela, $V$. pelagius, $V$. splendidus and the unclassified Vibrio P1. Although only $57.7 \%$ of the strains tested harbored one or more plasmids, the majority of the plasmid-containing strains $(93.3 \%)$ carried a large plasmid band of $34.4 \mathrm{MDa}$. A high number of isolates, regardless of their taxonomic group, were resistant to ampicillin and erythromycin. However, all the Vibrio strains were sensitive to chloramphenicol, tetracycline, gentamicin, nitrofurantoin, nalidixic acid and trimethoprim sulphamethoxazole No correlation between plasmid content and drug resistance was observed.
\end{abstract}

\section{INTRODUCTION}

Since summer 1988 several epizootic outbreaks causing high mortalities of manila clams Tapes philippinarum have appeared in the clam beds of Cadiz (southwestern Spain). The symptoms associated with these outbreaks are characterized by the presence of a brown deposit of organic matter on the inner surface of the shell, between the pallial line and the shell margins. The populations affected with brown ring disease (BRD) generally showed low development, shell deformities and mortality rates over $60 \%$. This disease was first reported in clam beds of Landeda (Finisterre, France) by Paillard et al. (1989), and has been extensively studied in France (Flassch 1989, Paillard \& Maes 1990, Maes et al. 1992) and in Spain (Castro et al 1990).

Paillard \& Maes (1990) proposed an infectious origin of the disease, the causative agent being identified as a Vibrio strain called P1. However, studies carried out in our laboratory indicate the presence of a varied micro- flora associated with this disease composed mainly of Vibrio species

In this study we have compared the biochemical and serological characteristics of the different strains isolated from affected clams in southwestern Spain. In addition, drug resistance and plasmid profiles of these strains were also analyzed.

\section{MATERIALS AND METHODS}

Sample processing. Samples of manila clams Tapes philippinarum affected with BRD symptoms were collected in different zones of the Cadiz Bay (Spain). In all the samplings, 100 specimens or more were collected and the incidence of the condition was recorded. Later, the clams with symptoms of BDR were microbiologically analyzed following the scheme described in Fig. 1. All the general and selective media employed for bacterial isolation were supplied by Difco. For longterm preservation, cultures were frozen at $-80^{\circ} \mathrm{C}$ in a 


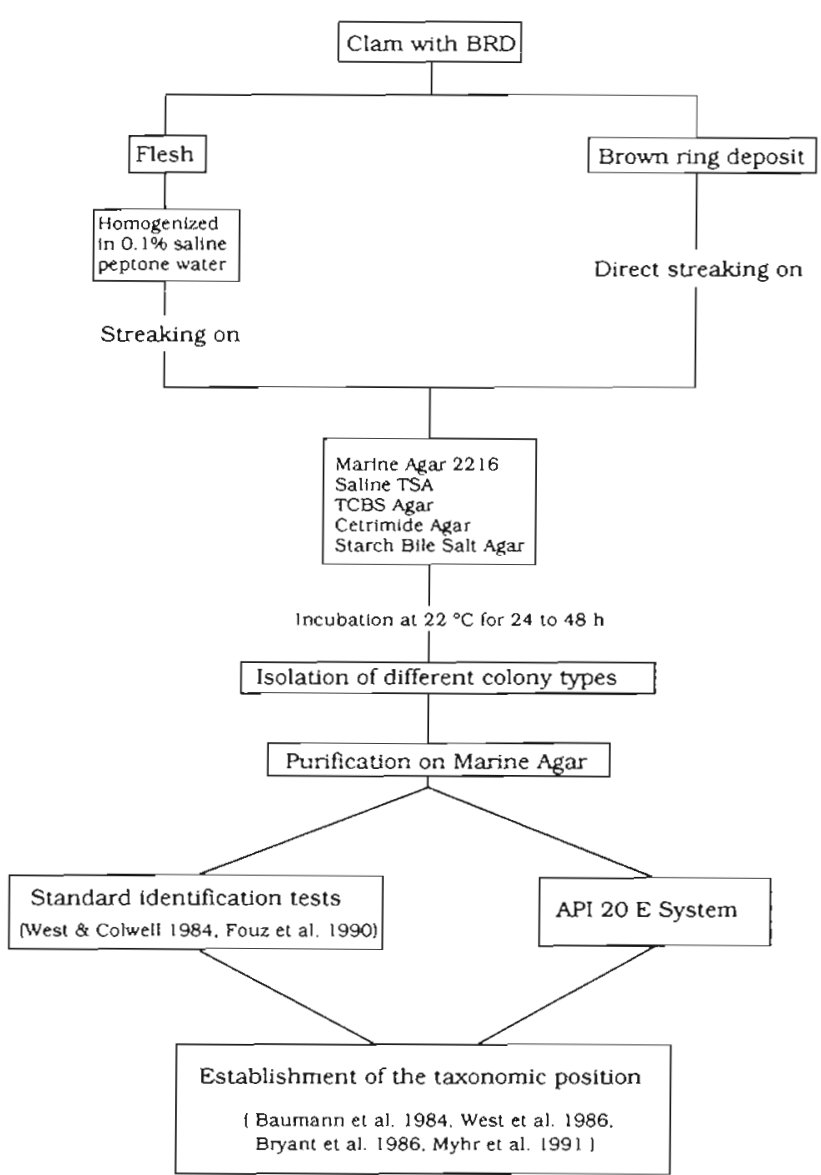

Fig. 1. Sample processing and bacterial identification procedure used in this study. TCBS: thiosulfate-citrate-bile-sucrose; TSA: tryptic soy agar

basal medium composed of $0.4 \%$ peptone (Difco), $0.1 \%$ yeast extract (Difco), $2 \% \mathrm{NaCl}$ and $15 \%$ (v/v) glycerol.

Biochemical and serological characterization. All strains were identified using 36 standard morphological, physiological and biochemical tests following the procedures of West \& Colwell (1984) and Fouz et al. (1990). In parallel, the commercial miniaturized API 20 E System (BioMerieux) was also employed using half strength seawater as diluent (Kent 1982).

The taxonomic position of the bacterial isolates was determined following mainly the criteria of Baumann et al. (1984), Bryant et al. (1986), West et al. (1986) and Myhr et al. (1991).

In order to examine the possible serological relationships among the Vibrio isolated in the present study and other related vibrios, slide agglutination tests were conducted as described by Sørensen \& Larsen (1986) and Toranzo et al. (1987a), using rabbit antisera raised against the following reference species: Vibrio anguillarum $\mathrm{O} 1$, strain $\mathrm{R}-82$ isolated from turbot; $V$. anguillanum O2, ATCC 19264; V. anguillarum O3, strain
13A5 isolated from water; $V$. tubiashii EX1 isolated from oysters; $V$. pelagius ATCC 25916; $V$. pelagius RG165 isolated from turbot; $V$ pelagius SG-12 isolated from salmon; $V$. splendidus ATCC 25914; $V$. damsela RG-191 isolated from turbot; and Vibrio P1 isolated from clams. To obtain these antisera, rabbits were injected intravenously with formalin killed cells twice weekly in consecutive doses of $0.2,0.4,0.8$ and $1 \mathrm{ml}$ $\left(10^{9}\right.$ cells $\left.\mathrm{ml}^{-1}\right)$. Rabbits were bled from the ear vein $1 \mathrm{wk}$ after the last injection. The blood was allowed to clot and the sera were collected and stored at $-30^{\circ} \mathrm{C}$ until used.

Reactions were performed using as antigens both the whole cells and the correspondent thermostable ' $O$ ' antigens, which were obtained by heating the bacterial suspensions $(10 \% \mathrm{~V} / \mathrm{v}$ in $\mathrm{PBS})$ at $100{ }^{\circ} \mathrm{C}$ for $1 \mathrm{~h}$ (Toranzo et al. 1987a). A strong agglutination occurring before $10 \mathrm{~s}$ was registered as a positive test.

Patterns of drug resistance. Antimicrobial resistance patterns of the isolates were determined by the disc diffusion method (Barry \& Thornsberry 1991) on Mueller Hinton agar (BioMerieux) supplemented with $1.5 \%$ $\mathrm{NaCl}$, using the following antimicrobial substances (ug $\left.\operatorname{disc}^{-1}\right)$ : ampicillin (10), streptomycin $(10)$, gentamicin (10), tobramycin (10), amikacin (30), kanamycin (30), chloramphenicol (30), tetracycline (30), erythromycin (15), nitrofurantoin (300), trimethoprim-sulphamethoxazole (25), and nalidixic acid (30). All the antibiotic discs were supplied by BioMerieux.

Plasmid detection. The isolation of plasmid DNA was carried out using the method of Kado \& Liu (1981) as modified by Toranzo et al. (1983). Cultures in exponential growth phase were centrifuged for $3 \mathrm{~min}$ at 12000 $\times \mathrm{g}$. Cell pellets were resuspended in $100 \mathrm{mM}$ Trisacetate buffer $(40 \mathrm{mM}$ Tris, $2 \mathrm{mM}$ sodium EDTA adjusted to $\mathrm{pH} 7.9$ with glacial acetic acid) and $200 \mathrm{l}$ of lysis solution (SDS $3 \%$ in $50 \mathrm{mM}$ Tris, $\mathrm{pH} \mathrm{12.4)} \mathrm{and}$ incubated at 55 to $60^{\circ} \mathrm{C}$ for $30 \mathrm{~min}$, after which the plasmid DNA was extracted with an equal volume of phenol-chloroform solution $(1: 1, v / v)$. The emulsion was separated by centrifugation for $10 \mathrm{~min}$ at $12000 \times \mathrm{g}$ at $4{ }^{\circ} \mathrm{C}$. The aqueous phase was removed and mixed with tracking dye solution (bromocresol purple $0.25 \%$ glycerol $50 \%$ in Tris-acetate buffer). DNA samples $(20 \mu \mathrm{l})$ were separated by horizontal electrophoresis in

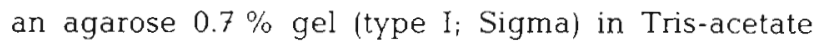
buffer at $75 \mathrm{~V}$ for about $3 \mathrm{~h}$. The gels were stained in ethidium bromide solution $0.5 \mathrm{\mu g} \mathrm{ml}^{-1}$, and photographed through a UV transilluminator with Kodak Imagelink film and 23A Wratten filter.

Reference plasmids from Escherichia coli V517 (containing 6 plasmids ranging from 35.8 to 1.4 megadaltons, MDa), E. coli R40a (96 MDa) and $V$. anguillarum 775 (47 MDa) were included as markers in the agarose gel electrophoresis. 


\section{RESULTS}

\section{Biochemical and serological characterization}

In total 189 strains isolated from clams affected with $\mathrm{BRD}$ were examined following the scheme specified in Fig. 1. All the isolates were included in the genus Vibrio, on the basis of the following characteristics: morphology and Gram stain (curved Gram-negative rod-shaped bacteria), motile, oxidase-positive, glu- cose-fermenting, and sensitive to the vibriostatic agent O/129 (150 $\mu \mathrm{g})$.

Each strain was examined for 36 additional physiological and biochemical characters which were compared with those exhibited by the Vibrio $\mathrm{P} 1$ reported as the causative agent of BRD in France (Paillard \& Maes 1990) (Table 1). All our strains possessed 27 common characteristics among themselves and with the Vibrio P1. However, our Vibrio isolates can be separated in 6 groups on the basis of 8 phenotypic traits: growth at

Table 1. Comparison of biochemical characteristics of Vibrio strains isolated from clams in Spain affected with brown ring disease with those of the French isolate Vibrio P1. n: No. of strains tested within each group; + : positive reaction; -: negative reaction; $\mathrm{V}$ : variable reaction among isolates, with no. of strains showing positive reaction in parentheses

\begin{tabular}{|c|c|c|c|c|c|c|c|}
\hline \multirow[t]{2}{*}{ Test } & \multicolumn{6}{|c|}{ Vibrio groups } & \multirow{2}{*}{ Vibrio $\mathrm{P} 1$} \\
\hline & $\begin{array}{c}1 \\
(\mathrm{n}=35)\end{array}$ & $\begin{array}{c}2 \\
(\mathrm{n}=49)\end{array}$ & $\begin{array}{c}3 \\
(\mathrm{n}=14)\end{array}$ & $(\mathrm{n}=21)$ & $\begin{array}{c}5 \\
(\mathrm{n}=34)\end{array}$ & $\begin{array}{c}6 \\
(\mathrm{n}=34)\end{array}$ & \\
\hline \multicolumn{8}{|l|}{ Common characteristics } \\
\hline \multicolumn{8}{|l|}{ Growth in: } \\
\hline $0 \% \mathrm{NaCl}$ & - & - & - & - & - & - & - \\
\hline $3 \% \mathrm{NaCl}$ & + & + & + & + & + & + & + \\
\hline $10 \% \mathrm{NaCl}$ & - & - & - & - & - & - & - \\
\hline \multicolumn{8}{|l|}{ Growth at: } \\
\hline $15^{\circ} \mathrm{C}$ & + & + & + & + & + & + & + \\
\hline $22^{\circ} \mathrm{C}$ & + & + & + & + & + & + & + \\
\hline Growth on TCBS & + & + & + & + & + & + & + \\
\hline Nitrate reduction & + & + & + & + & + & + & + \\
\hline Urease & - & - & - & - & - & - & - \\
\hline $\mathrm{H}_{2} \mathrm{~S}$ production & - & - & -- & - & - & - & - \\
\hline Motility & + & + & + & + & + & + & + \\
\hline Indole & + & + & + & + & + & + & + \\
\hline Lysine decarboxylase & - & - & - & - & - & - & - \\
\hline Ornithine decarboxylase & - & - & - & - & - & - & - \\
\hline Tryptophane deamynase & - & - & - & - & - & - & - \\
\hline Gas from glucose & - & - & - & - & - & - & - \\
\hline \multicolumn{8}{|l|}{ Acid from: } \\
\hline Glucose & + & + & + & + & + & + & + \\
\hline Mannose & + & + & $t$ & + & + & + & + \\
\hline Fructose & + & + & + & + & + & + & + \\
\hline Galactose & + & + & + & + & + & + & + \\
\hline Inositol & - & - & - & - & - & - & - \\
\hline Sorbitol & - & - & - & - & - & - & - \\
\hline Rhamnose & - & - & - & - & - & - & - \\
\hline Melobiose & - & - & - & - & - & - & - \\
\hline Arabinose & - & - & - & - & - & - & - \\
\hline Utilization of citrate & - & - & - & - & - & - & - \\
\hline Amylase & + & + & + & + & + & + & + \\
\hline Lipase & + & + & + & + & + & + & + \\
\hline \multicolumn{8}{|l|}{ Differential characteristics } \\
\hline Growth at $4{ }^{\circ} \mathrm{C}$ & - & - & - & - & - & - & + \\
\hline Growth at $35^{\circ} \mathrm{C}$ & + & - & + & - & + & + & - \\
\hline ONPG & $V(21)$ & - & $V(10)$ & $V(14)$ & - & - & + \\
\hline Voges-Proskauer & $V(28)$ & - & - & - & $V(20)$ & - & - \\
\hline Arginine dihydrolase & - & - & - & - & + & + & - \\
\hline \multicolumn{8}{|l|}{ Acid from: } \\
\hline Sucrose & + & + & - & - & + & - & - \\
\hline Amygdalin & + & + & $V(8)$ & + & - & + & - \\
\hline Mannitol & + & + & + & + & $V(19)$ & + & - \\
\hline Gelatinase & + & + & $V(12)$ & - & + & + & + \\
\hline
\end{tabular}


$35^{\circ} \mathrm{C}$, ONPG, Voges-Proskauer, arginine dihydrolase, acid production from sucrose, amygdalin and mannitol, and gelatinase activity (Table 1 ).

Group 1 contained strains that resemble those described by West et al. (1986) as unidentified marine Vibrio sp. and included in the phenons 19 and 34 (Vibrio sp.) by Bryant et al. (1986). The differential characteristics of the strains of this group are: positive growth at $35^{\circ} \mathrm{C}$, variable reactions for $O N P G$ and Voges-Proskauer tests, production of acid from sucrose, amygdalin and mannitol, production of gelatinase, and negative reaction for arginine dihydrolase. The strains belonging to Groups 2 and 4 do not grow at $35^{\circ} \mathrm{C}$, and are negative for the tests Voges-Proskauer and arginine dihydrolase, but they produce acid from amygdalin and mannitol. The differentiation of both groups is based on the gelatinase activity and the acid production from sucrose. None of the 433 strains studied by West et al. (1986) coincide with the biochemical profiles of the strains of these groups, but are very similar to the phenon 50 (Vibrio sp.) proposed by Bryant et al. (1986).

Only 14 strains could be isolated in Group 3, whose differential characteristics resemble other strains belonging to Vibrio pelagius, according to the classifications of West et al. (1986) and Bryant et al. (1986). Groups 5 and 6 comprised strains with very similar biochemical characteristics, and their differentiation from other groups is the presence of the enzyme arginine dehydrolase. Group 5 corresponds with the phenons 12 and 13 of Bryant et al. (1986), which are Vibrio sp., and Group 6 resembles the phenon 25. classified as $V$. splendidus I.

On the other hand, on the basis of the biochemical characterization of 264 strains isolated from diseased and healthy fish carried out by Myhr et al. (1991), our isolates can be included into the following species: Groups 1 and 2 as Vibrio pelagius bv. II, Groups 3 and 4 could be assigned to either $V$. pelagius bv. II or $V$. splendidus bv. II, and Groups 5 and 6 to $V$. splendidus bv. I. Interestingly, the Group 5 strains also share some characteristics with $V$. tubiashii and $V$. anguillarum. Although the French isolate Vibrio P1 seems to be very similar to our Group 3, the most important differential traits are the capacity of the P1 strain to grow at $4{ }^{\circ} \mathrm{C}$, and its unability to support $35^{\circ} \mathrm{C}$ and to produce acid from mannitol (Table 1).

In another phase of this study, strains of each group were compared serologically with reference Vibrio strains isolated from fish and shellfish (Table 2). Each strain showed an antigenic homogeneity only with the antiserum obtained from itself. However, none of the isolates presented a cross-reaction with the antisera for other strains. On the basis of these findings, it can be deduced that although there are biochemical similarities among the strains isolated in the present study with the species $V$. pelagius- $V$. splendidus- $V$. tubiashii- $V$. anguillarum, serological analyses demon-

Table 2. Slide agglutination reactions using as antigens both the whole cells and the somatic $O$ antigens. $n$ : No. of strains tested within each group; ++ : strong agglutination within $10 \mathrm{~s} ;--$ : negative agglutination

\begin{tabular}{|c|c|c|c|c|c|c|c|c|c|c|}
\hline \multirow[t]{2}{*}{ Ontigens } & \multicolumn{10}{|c|}{ Rabbit antisera } \\
\hline & $\mathrm{R}-82$ & 19264 & 13 A5 & $\mathrm{EX} 1$ & 25916 & RG-165 & SG-12 & 25914 & RG-191 & P1 \\
\hline \multicolumn{11}{|l|}{ Vibrio groups } \\
\hline Group $1(\mathrm{n}=7)$ & - & - & - & - & - & - & - & - & - & - \\
\hline Group $2(n=10)$ & - & - & - & - & - & - & - & - & - & - \\
\hline Group $3(n=3)$ & - & - & - & - & - & - & - & - & - & - \\
\hline Group $4(n=6)$ & - & - & - & - & - & - & - & - & - & - \\
\hline Group $5(n=10)$ & - & - & - & - & - & - & - & - & - & - \\
\hline Group $6(n=7)$ & - & - & - & - & - & - & - & - & - & - \\
\hline \multicolumn{11}{|l|}{ Reference strains } \\
\hline V. anguillarum $\mathrm{R}-82(\mathrm{O} 1)^{\mathrm{a}}$ & ++ & - & - & - & - & - & - & - & - & - \\
\hline V. anguillarum ATCC $19264(\mathrm{O} 2)^{\mathrm{d}}$ & - & ++ & - & - & - & - & - & - & - & - \\
\hline$V$ anguillarum $13 \mathrm{~A} 5(\mathrm{O} 3)^{\mathrm{a}}$ & - & - & ++ & - & - & - & - & - & - & - \\
\hline V.tubiashii EX 1 & - & - & - & ++ & - & - & - & - & - & - \\
\hline$V$. pelagius ATCC 25916 & - & - & - & - & ++ & - & - & - & - & - \\
\hline V. pelagius RG-165 & - & - & - & - & - & ++ & - & - & - & - \\
\hline V. pelagius SG-12 & - & - & - & - & - & - & ++ & - & - & - \\
\hline V. splendidus ATCC 25914 & - & - & - & - & - & - & - & ++ & - & - \\
\hline V. damsela RG-191 & - & - & - & - & - & - & - & - & ++ & - \\
\hline Vibrio $\mathrm{P} 1$ & - & - & - & - & - & - & - & - & - & ++ \\
\hline
\end{tabular}


strate that antigenic identities do not exist among the groups.

\section{Drug resistance patterns}

Determination of resistance patterns to 12 antibiotics showed that of the 100 strains tested, $84 \%$ were resistant to at least 1 antimicrobial drug (Table 3). All groups showed resistance, in different degrees, to ampicillin and erythromycin, and were susceptible to gentamicin, chloramphenicol, tetracycline, nitrofurantoin, trimethoprim-sulphametoxazole and nalidixic acid. The resistance to streptomycin, tobramycin, amikacin and kanamycin was variable among the groups. Total resistance of Groups 2, 3 and 6 was observed only for ampicillin, which may be used as an additional tool to discriminate among the Vibrio groups.

Our results showed higher percentages of resistance in the present isolates than in other species belonging to the same genus and isolated from several sources (Kelch \& Lee 1978, Beringer \& Hirsch 1984, Myhr et al. 1991). Resistance patterns seem to be independent of the taxonomic inclusion of the strains in different Vibrio groups.

\section{Plasmid content of selected strains involved in BRD}

Twenty-six strains in the 6 groups of vibrios implicated in BRD were examined for plasmids, as described above. Only $57.7 \%$ of the strains harbored 1 or more plasmids ranging from 1.1 to $34.4 \mathrm{MDa}$ (Table 4). Interestingly, practically all the strains carrying plasmids contained the 34.4 MDa band. This plasmid was harbored alone or in combination with low molecular weight $(<10 \mathrm{MDa})$ plasmids.

\section{DISCUSSION}

Vibriosis is one of the most threatening diseases in fish and shellfish cultures in marine waters. Among the great number of species recognized within the genus Vibrio, only 8 have been described as important pathogens for aquatic animals: $V$ anguillarum, $V$. ordalii, $V$. tubiashi, $V$. damsela, $V$. vulnificus, $V$. salmonicida, $V$. carchariae and $V$. cholerae non-O1. However, vibrioses caused by $V$. anguillarum and $V$. tubiashii are the most serious bacterial infections limiting the production of marine fish and shellfish over the world (Toranzo \& Barja 1990).

On the other hand, there are vibrios in the estuarine environment taxonomically and serologically related to Vibrio anguillarum and V. tubiashii (Bryant et al. 1986. Fouz et al. 1990) which, although usually considered strains without pathogenic significance, have recently been associated with diseases in marine fish, molluscs and crustaceans (Lupiani et al. 1989, Masumura et al. 1989, Baticados et al. 1990, Fouz et al. 1990, LavillaPitogo et al. 1990, Toranzo et al. 1990, Myhr et al. 1991). These vibrios correspond mainly to different biotypes of $V$. splendidus and $V$. pelagius and can be compiled under the general designation of $V$. anguillarumrelated (VAR) organisms (Larsen 1983, 1985, Fouz et al. 1990, Myhr et al. 1991). Table 5 presents important differential phenotypic traits among these VAR species and the most substantiated pathogenic vibrios for poikilothermic animals which can be useful for diagnostic purposes. Although in the present work all the isolates from diseased clams belonged to different groups of $V$. pelagius and $V$. splendidus (Table 1 ), in some cases a clear distinction between these 2 species is difficult because of the number of variable reactions existing within the strains of each species (Table 5).

Table 3. Drug resistance patterns (\% of resistance) of the Vibrio strains isolated from clams affected with brown ring disease $\mathrm{n}$ : No. of strains tested

\begin{tabular}{|c|c|c|c|c|c|c|}
\hline $\begin{array}{l}\text { Chemotherapeutic } \\
\text { agents }\end{array}$ & $\begin{array}{l}\text { Group } 1 \\
(\mathrm{n}=20)\end{array}$ & $\begin{array}{l}\text { Group 2 } \\
(\mathrm{n}=20)\end{array}$ & $\begin{array}{l}\text { Group } 3 \\
(\mathrm{n}=10)\end{array}$ & $\begin{array}{l}\text { Group } 4 \\
(\mathrm{n}=10)\end{array}$ & $\begin{array}{l}\text { Group } 5 \\
(n=20)\end{array}$ & $\begin{array}{l}\text { Group } 6 \\
(\mathrm{n}=20)\end{array}$ \\
\hline Ampicillin & 60 & 100 & 100 & 60 & 80 & 100 \\
\hline Streptomycin & 20 & 15 & 0 & 30 & 0 & 20 \\
\hline Gentamicin & 0 & 0 & 0 & 0 & 0 & 0 \\
\hline Tobramycin & 20 & 30 & 0 & 30 & 0 & 0 \\
\hline Amikacin & 0 & 30 & 0 & 60 & 0 & 0 \\
\hline Kanamycin & 0 & 15 & 50 & 30 & 20 & 0 \\
\hline Chloramphenicol & 0 & 0 & 0 & 0 & 0 & 0 \\
\hline Tetracycline & 0 & 0 & 0 & 0 & 0 & 0 \\
\hline Erythromycin & 60 & 60 & 50 & 30 & 40 & 20 \\
\hline Nitrofurantoin & 0 & 0 & 0 & 0 & 0 & 0 \\
\hline Nalidixic acid & 0 & 0 & 0 & 0 & 0 & 0 \\
\hline $\begin{array}{l}\text { Trimethoprim- } \\
\text { sulphamethoxazole }\end{array}$ & 0 & 0 & 0 & 0 & 0 & 0 \\
\hline
\end{tabular}


Table 4. Plasmid profiles and antimicrobial susceptibility of several Vibrio strains involved in brown ring disease. Ap: Ampicillin; Sm: streptomycin; NN: tobramycin; E: erythromycin; An: amikacin; Km: kanamycin; -: sensitive strains

\begin{tabular}{|c|c|c|c|}
\hline \multirow[t]{2}{*}{ Strain } & \multicolumn{2}{|c|}{ Plasmid profiles } & \multirow{2}{*}{$\begin{array}{c}\text { Antimicrobial resistance } \\
\text { patterns }\end{array}$} \\
\hline & No. & Sizes (MDa) & \\
\hline \multicolumn{4}{|l|}{ Group 1} \\
\hline V 519 & 0 & - & - \\
\hline V 543 & 0 & - & $\mathrm{Ap}, \mathrm{Sm}, \mathrm{NN}, \mathrm{E}$ \\
\hline V 556 & 2 & $34.4,5.1$ & $\mathrm{Ap}, \mathrm{E}$ \\
\hline V 558 & 0 & - & $\mathrm{Ap}, \mathrm{E}$ \\
\hline $\mathrm{Cl}-8 \mathrm{G}$ & 1 & 34.4 & - \\
\hline \multicolumn{4}{|l|}{ Group 2} \\
\hline V 526 & 0 & - & Ap, Sm, NN, An, E \\
\hline V 538 & 0 & - & $\mathrm{Ap}$ \\
\hline V 540 & 0 & - & $\mathrm{Ap}, \mathrm{E}$ \\
\hline V 542 & 1 & 34.4 & Ap \\
\hline V 555 & 1 & 34.4 & $\mathrm{Ap}, \mathrm{Km}, \mathrm{E}$ \\
\hline V 557 & 2 & $34.4,6.0$ & $A p, E$ \\
\hline V 559 & 1 & 34.4 & $A p, N N, A n$ \\
\hline \multicolumn{4}{|l|}{ Group 3} \\
\hline V 525 & 2 & $34.4,7.4$ & Ap, E \\
\hline V 568 & 2 & $34.4,15.0$ & $\mathrm{Ap}, \mathrm{Km}$ \\
\hline \multicolumn{4}{|l|}{ Group 4} \\
\hline V 528 & 0 & - & $N N_{1} A N$ \\
\hline AM 112 & 6 & $34.4,15.0,2.9,2.4,2.0,1.1$ & Ap \\
\hline \multicolumn{4}{|l|}{ Group 5} \\
\hline V 521 & 0 & - & Ap \\
\hline V 541 & 1 & 34.4 & Ap \\
\hline V 548 & 1 & 34.4 & $\mathrm{Ap}, \mathrm{E}$ \\
\hline V 551 & 1 & 34.4 & $\mathrm{Ap}, \mathrm{Km}$ \\
\hline $\mathrm{Cl}-16 \mathrm{G}$ & 0 & - & $E$ \\
\hline \multicolumn{4}{|l|}{ Group 6} \\
\hline V 529 & 0 & - & Ap \\
\hline V 539 & 1 & 7.4 & $\mathrm{Ap}, \mathrm{Sm}$ \\
\hline V 549 & 1 & 34.4 & Ap \\
\hline V 560 & 1 & 34.4 & $\mathrm{Ap}$ \\
\hline AM 113 & 0 & - & Ap, E \\
\hline
\end{tabular}

None of the Vibrio strains analyzed in our study were serologically related with the classic pathogenic serotypes of $V$. anguillarum or $V$. tubiashii. However, we cannot rule out that some of the $V$. splendidus bv. I positive for arginine dehydrolase and utilization of sucrose (Group 5) could belong to the environmental serotypes (from O4 to O10) of $V$. anguillarum (Sørensen $\&$ Larsen, 1986). In fact, it was found recently that some $V$. splendidus associated with diseases in marine fish in northwestern Spain should be assigned to the serotypes $\mathrm{O} 4$ and $\mathrm{O} 5$ of $V$. anguillarum (Pazos et al. 1992).

There are several studies of pathogenic vibrios regarding the possible correlation between the presence of plasmid and virulence properties. Although for some species, such as Vibrio ordalii and $V$. salmonicida, it was reported that the majority of the isolates harbor a 23 and $21 \mathrm{MDa}$ plasmid respectively (Schiewe \& Crosa 1981, Wiik et al. 1989a), their role with pathogenicity was not demonstrated. At present, only in the serotype $\mathrm{O} 1$ of $V$. anguillarum was the presence of a plasmid of $47 \mathrm{MDa}$ clearly associated with the virulence of these strains (Crosa 1984, Toranzo et al. 1987b, Wiik et al. 1989b, Conchas et al. 1991). This plasmid mediates a very efficient iron-sequestering system which allows bacteria to grow at the low concentrations of available iron in the host tissue (Walter et al. 1983, Tolmasky et al. 1985, Wolf \& Crosa 1986). In the present study, regardless of taxonomic group or drug resistance pattern, a plasmid of 34.4 MDa was found in the majority of the plasmid-containing isolates (93.3\%) (Table 4). These findings support the fact that these $V$. pelagius- $V$. splendidus groups must be closely related phylogenetically and can represent phenotypic variants of a major and unique group.

Since it is not possible to establish a clear association of a particular Vibrio group with the BRD, other factors may be involved such as: (1) physiological conditions of the clams seeded, (2) seed density in the clam bed, and (3) influence of environmental factors, such as insolation, tide, and type of clam bed. These stress conditions 


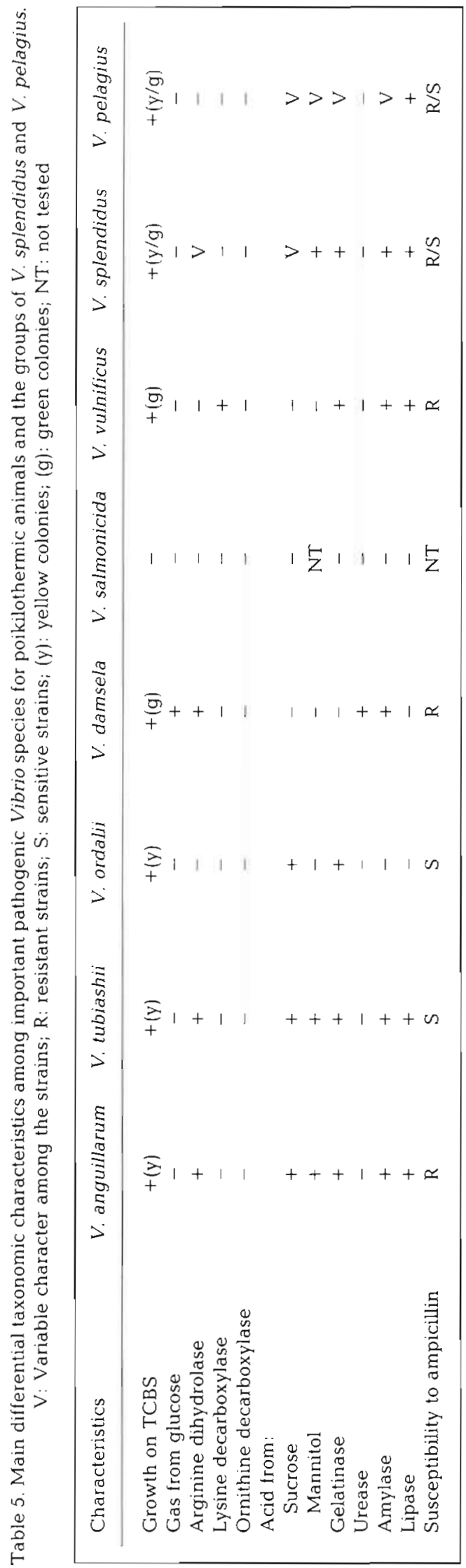

can favor the selection and subsequent proliferation of the $V$. splendidus and $V$. pelagius groups which become dominant among the marine microflora of both water and molluscs. In addition, some of these dominant Vibrio strains can possess the pathogenic potential needed to produce mortality in shellfish previously weakened by stressing factors (Baticados et al. 1990, Lavilla-Pitogo et al. 1990). In fact, we have previously demonstrated that the microflora of healthy clams is composed of a varied bacterial population that includes: $V$. harveyi, $V$. alginolyticus, $V$. splendidus, $V$. pelagius, $V$. nereis, $V$. fluvialis, $V$. costicola, Aeromonas sp. and Pseudomonas sp. (Castro et al. 1990).

Further studies on the virulence factors and pathogenicity for molluscs of the VAR microorganisms are being conducted to assess their possible implication in brown ring disease.

Acknowledgements. This study was supported by grants from the Dirección General de Investigación y Tecnología de Pesca de la Consejería de Agricultura y Pesca, Junta de Andalucia, Grant MAR 91-1133-CO2-01 from the Comisión Interministerial de Ciencia y Tecnología (CICYT), Spain, and Grant AQ-1263 from the EEC. B. Fouz acknowledges the Xunta de Galicia for a Research Fellowship. The authors thank Philippe Maes, Laboratoire de Biologie Marine, Université de Bretagne Occidentale, Brest Cedex, France, for the kindly supply of the Vibrio P1 strain.

\section{LITERATURE CITED}

Barry, A. L., Thornsberry, C. (1991). Susceptibility tests: diffusion test procedures. In: Balows, A., Hausler, W. J. Jr Herrmann, K. L., Isenberg, H. D., Shadomy, H. J. (eds.) Manual of clinical microbiology. American Society for Microbiology, Washington, D.C., p. 1117-1125

Baticados, M. C. L., Lavilla-Pitogo, C. R., Cruz-Lacierda, E. R., de la Peña, L. D., Suñaz, N. A. (1990). Studies on the chemical control of luminous bacteria Vibrio harveyi and $V$. splendidus isolated from diseased Penaeus monodon larvae and rearing water. Dis. aquat. Org. 9: 133-139

Baumann, P., Furniss, A. L., Lee, J. V (1984). Genus 1. Vibrio Pacini 1854, 411 AL In: Krieg, N. R., Holt, J. G. (eds.) Bergey's manual of systematic bacteriology, Vol. 1. Williams \& Wilkins Co., Baltimore, p. 518-538

Beringer, J. E., Hirsch, P. R. (1984). Genetic adaptation to the environment. The role of plasmids in microbial ecology. In: Klug, M. J., Reddy, C. A. (eds.) Current perspectives in microbial ecology. Proc. 3rd Int. Symp. Microbial Ecology, Michigan State Univ. American Society for Microbiology, Washington, D.C., p. 63-70

Bryant, T. N., Lee, J. V., West, P. A., Colwell, R. R. (1986) Numerical classification of species of Vibrio and related genera. J. appl. Bacteriol. 61: 437-467

Castro, D., Moriñigo, M. A., Cornax, R., Martinez-Manzanares, E., Borrego, J. J. (1990). Microflora associated with outbreaks of 'brown ring' from clams (Tapes semidecussatus) cultured in Southwestern Spain. In: Figueras, A., Fisher, W. S., van Banning, P. (eds.) Fourth Int. Colloquium on Pathology in Marine Aquaculture. Instituto Investigaciones Marinas, Vigo, Spain, p. 56 
Conchas, R. F., Lemos, M. L., Barja, J. L., Toranzo, A. E. (1991) Distribution of plasmid-and chromosome-mediated iron uptake systems in Vibrio anguillarum strains of different origins. Appl. environ. Microbiol. 57. 2956-2962

Crosa, J. H. (1984). The relationship of plasmid-mediated iron transport and bacterial virulence. A. Rev. Microbiol. 38: 69-89

Flassch, J. P. (1989). Bilan des travaux sur la maladie des anneaux bruns chez la palourde d'elevage. Equinoxe 29: $9-11$

Fouz, B., Conchas, R. D., Bolinches, J., Romalde, J. L., Barja, J. L., Toranzo, A. E. (1990). Relationships among pathogenic Vibrio anguillarum and Vibrio tubiashii with environmental vibrios. In: Perkins, F. O., Cheng. T. C. (eds.) Pathology in marine science. Academic Press, New York, p. 77-89

Kado, C. I., Liu, S. T (1981). Rapid procedure for detection and isolation of large and small plasmids. J. Bacteriol. 145 1365-1373

Kelch, W. J., Lee, J. V. (1978). Antibiotic resistance patterns of gram-negative bacteria isolated from environmental sources. Appl. environ. Microbiol. 36: 450-456

Kent, M. L. (1982) Characteristics and identification of Pasteurella and Vibrio species pathogenic to fishes using API20E (Analytab Products) Multitube test strips. Can. J. Fish. Aquat. Sci. 39: 1725-1729

Larsen, J. L. (1983). Vibrio anguillarum: a comparative study of fish pathogenic, environmental, and reference strains. Acta vet. scand. $24: 456-476$

Larsen, J. L. (1985). Vibrio anguillarum: prevalence of typical and atypical strains in marine recipients with special reference to carbohydrate pollution. Acta vet. scand. 26: 449-460

Lavilla-Pitogo, C. R., Baticados, M. C. L., Cruz-Lacierda, E. R. de la Peña, L. D. (1990). Occurrence of Iuminous bacterial disease of Penaeus monodon larvae in the Philippines Aquaculture 91. 1-13

Lupiani, B., Dopazo, C. P., Ledo, A., Fouz, B., Barja, J. L. (1989). New syndrome of mixed bacterial and viral etiology in cultured turbot Scophthalmus maximus. J. aquat. anim. Hith 1: 197-204

Maes, P., Paillard, C., Le Pennec, M., Marhic, A. (1992). The brown ring disease of Ruditapes philippinarum: bacterial analysis. In: Vivares, C. P. (ed.) Fifth Int. Colloquium on Pathology in Marine Aquaculture. BIOCIM, Montpellier France, p. 32

Masumura, K., Yasunobu, H., Okada, N., Muroga, K. (1989) Isolation of a Vibrio sp., the causative bacterium of intestinal necrosis of Japanese flounder larvae. Fish Pathol. 24: $135-141$

Myhr, E., Larsen, J. L., Lillehaug, A., Gudding, R., Heum, M., Hastein, T. (1991). Characterization of Vibrio anguillarum and closely related species isolated from farmed fish in Norway. Appl. environ. Microbiol. 57: 2750-2757

Paillard, C., Maes, P. (1990). Etiologie de la maladie de l'anneau brun chez Tapes philippinarum: pathogénicité d'un Vibrio sp. C. r. Acad. Sci., Paris 310: 15-20

Paillard, C., Percelay, L., Le Pennec, M., Le Picard, D. (1989).

Responsible Subject Editor: A. K. Sparks, Seattle,

Washington, USA
Origine pathogène de l'anneau brun chez Tapes philippinarum (Mollusque, bivalve). C. r Acad. Sci., Paris 309 : $235-241$

Pazos, F., Santos, Y., Magarin̄os, B., Toranzo, A. E. (1992). Taxonomical and serological relationship among Vibrio species isolated from fish. In: Vivares C. P. (ed.) Fifth Int. Colloquium on Pathology in Marine Aquaculture. BIOCIM, Montpellier, France, p. 45

Schiewe, M. H., Crosa, J. H. (1981). Molecular characterization of Vibrio anguillarum biotype 2. Can. J. Microbiol. 27: $1011-1018$

Serensen, U. B. S., Larsen, J. L. (1986). Serotyping of Vibrio anguillarum. Appl. environ. Microbiol. 51: 593-597

Tolmasky, M. E., Actis, L. A., Toranzo, A. E., Barja, J. L., Crosa, J. H. (1985). Plasmid mediated iron uptake in Vibrio anguillarum strains isolated from turbot in Spain. J. gen. Microbiol. 131: 1989-1997

Toranzo, A. E., Barja, J. L. (1990). A review of the taxonomy and seroepizootiology of Vibrio anguillarum, with special reference to aquaculture in the northwest of Spain. Dis. aquat. Org. 9: 73-82

Toranzo, A. E., Barja, J. L., Colwell, R. R., Hetrick, F. M. (1983). Characterization of plasmids in bacterial fish pathogens. Infect. Immun. 39: 184-192

Toranzo, A. E., Baya, A. M., Roberson, B. S., Barja, J. L., Grimes, D. J., Hetrick, F. M. (1987a). Specificity of slide agglutination test for detecting bacterial fish pathogens. Aquaculture 67: 81-97

Toranzo, A. E., Santos, Y., Lemos, M. L., Ledo, A., Bolinches, J. (1987b). Homology of Vibrio anguillarum strains causing epizootics in turbot, salmon, and trout reared on the Atlantic coast of Spain. Aquaculture 67: 41-52

Toranzo, A. E., Santos, Y., Bandin, I., Romalde, J. L., Ledo, A. Fouz, B., Barja, J. L. (1990). Five-year survey of bacterial fish infections in continental and marine aquaculture in Northwest Spain. WId Aquaculture 21: 91-94

Walter, M. A., Potter, S. A., Crosa, J. H. (1983). Iron uptake system mediated by Vibrio anguillarum plasmid pJM1. J. Bacteriol. 156: 880-887

West, P. A., Brayton, P. R., Bryant, T N., Colwell, R. R. (1986). Numerical taxonomy of vibrios isolated from aquatic environments. Int. J. syst. Bacteriol. 36: 531-543

West, P. A., Colwell, R. R. (1984). Identification and classification of Vibrionaceae. An overview. In: Colwell, R. R. (ed.) Vibrios in the environment. John Wiley, New York, p. 285-363

Wiik, R., Andersen, K., Daae, F. L., Hoff, K. A. (1989a). Virulence studies based on plasmid profiles of the fish pathogen Vibrio salmonicida. Appl. environ. Microbiol. 55: 819-825

Wiik, R., Hoff, K. A., Andersen, K., Daae, F. L. (1989b). Relationships between plasmids and phenotypes of presumptive strains of Vibrio anguillarum isolated from different fish species. Appl. environ. Microbiol. 55: 826-831

Wolf, M., Crosa, J. H. (1986). Evidence for the role of a siderophore in promoting Vibrio anguillarum infections. $J$. gen. Microbiol. 32: 2949-2952

Manuscript first received: March 27, 1992

Revised version accepted: August 17, 1992 